\title{
A contradiction in terms?: migrant activists in the Sweden Democrats party
}

Diana Mulinari and Anders Neergaard

The self-archived postprint version of this journal article is available at Linköping University Institutional Repository (DiVA):

http:/ / urn.kb.se/ resolve?urn=urn:nbn:se:liu:diva- 144870

N.B.: When citing this work, cite the original publication.

This is an electronic version of an article published in:

Mulinari, D., Neergaard, A., (2018), A contradiction in terms?: migrant activists in the Sweden

Democrats party, Identities, , 1-19. https:// doi.org/ 10.1080/ 1070289X.2017.1418275

Original publication available at:

https:/ / doi.org/ 10.1080/ 1070289X.2017.1418275

Copyright: Taylor \& Francis (Routledge) (SSH Titles)

http:/ / www.routledge.com/ 
A contradiction in terms? Migrant activists in the Sweden Democrats party

\section{Introduction}

Right-wing, xenophobic and racist parties have enjoyed immense successes in Europe in recent decades (Mudde 2010; Keskinen 2014). In Sweden, the third-largest party in Parliament is the Sweden Democrats (SD), with 13\% in the 2014 general election. Growing scholarship on the SD has identified the party's historical roots in neo-Nazism, fascism and biological racism and traced the party’s trajectory towards electoral success (Ekman and Poohl 2010). Surveys indicate a strong over-representation of white Swedish males among the party's supporters, reflected in its representatives in municipal governments and the national Parliament (Mulinari and Neergaard 2017a).

Sympathy for the SD among foreign-born Swedish residents, both women and men, is far lower than among Sweden-born men, but an increasing number of Swedish citizens with migrant backgrounds support the party. To a certain extent, it can seem contradictory for a citizen with a migrant background to become a member and a representative of a racist party that calls refugees and migrants, especially Muslims, the principal threat to Sweden. The involvement of citizens with migrant backgrounds in the SD raises the question of what subject positions (Davies and Harre 1990) racialised groups are allowed to act upon in Sweden within not only parliamentary politics but also discourses of national belonging (Anthias 2002; Skey 2011). The aim of this article is to explore the subject positions open for citizens with migrant background with special focus on the identities and worldviews developed by migrant activists who have joined the SD party and are, to differing degrees, racialised and perceived as non-Swedish. ${ }^{i}$ Using the concept of migrant respectability, this research is intended to understand why and under what circumstances migrants chose to join and represent a xenophobic and racist party. 


\section{Migrants and the political: The Swedish context}

Sweden frequently has been cited as one of the most successful political projects of social-democratic welfare regimes (Esping-Andersen 1990), state-led gender-equality politics (Melby, Ravn and Wetterberg 2008) and multiculturalism (Ålund and Schierup 1991; Castles and Miller 2003). While the nation still scores high in various evaluations of social justice, equality and inclusion, it has seen dramatic shifts in recent years that have led some authors to pose the question of 'the end of Swedish exceptionalism' (Schierup and Ålund 2011). Even at the peak of Sweden's most inclusive multicultural policies, with comparatively low degrees of inequalities between inhabitants of Swedish and foreign backgrounds, scholars noted substantial democratic deficits in the underrepresentation of migrants as voters and as political representatives (Göransson 2005). Culturalised discourses emphasising migrants’ political passivity has been challenged by researchers identifying forms of subordinated inclusion enforced by exclusionary and discriminatory practices (Dahlstedt and Hertzberg 2005).

As in other western countries (Castles and Kosak 1973; Peró and Solomos 2011), labour-market policies, combined with processes of racialisation, forged a division of labour relegating migrants to employment characterised by the 'three Ds': dirty, dangerous and demeaning. Although Sweden had high unionisation rates, studies reported that migrants faced experiences of discrimination in unions (Neergaard and Woolfson 2017). An us-vsthem opposition, often articulated in the paternalist phrase 'we and our migrants', regulated the forms of subordinated inclusion encountered in Swedish unions by highly skilled union activists with migrant backgrounds. Multiculturalist policies created room for the emergence of often ethnic-coded migrant organisations that simultaneously grew parallel to and tended to replace union organisation among migrants (Ålund and Schierup 1991). Within both unions and ethnic-coded migrant organisations, the institutionalisation of subordinated inclusion went hand in hand with migrant practices of respectability (Mulinari and Neergaard 2004). 
The shift towards neoliberalism that took place in the beginning of the nineties developed alongside increasing forms of assimilationist policies targeting the 'Migrant Other', especially through discourses of racism towards (people perceived as) Muslims (Gardell 2010; Mulinari and Neergaard 2012).

Historically, a strong link has existed between the Social Democratic Party (SDP) and citizens of migrant backgrounds in parliamentary elections (Bäck and Soininen 1998), with the SDP historically gaining well above $50 \%$ of votes among this group. This structural pattern, though, has been trending downward since 2006, with increasing numbers of migrant voters supporting right-wing parties (support for the SDP does remain consistently 10\%-20\% higher among foreign-born than Swedish-born voters) (Statistics Sweden [SCB] n.d,). The traditionally conservative Moderate Party (Moderaterna) has gradually modified its exclusionary conservative profile in favour of a more neoliberal and individualistic programme, challenging what it decries as an oppressive, backward welfare state. The party positions this move as a liberating initiative for migrants, as reflected in the programme platform 'Country for the hopeful’ (Land för Hoppfullaii).

The increasing heterogeneity of the migrant vote may be explained by a number of factors, including the effect of growing strata of migrants with better labour-market positions, the crisis in the SDP's project and challenges from right-wing parties more explicitly targeting migrant communities as scape-goats in a public context where migration has gradually been reformulated as a problem and threat to Sweden and as the SD has enjoyed growing popularity.

\section{Sweden Democrats: The successful remaking of a racist party}

Formed in 1988 from the remnants of neo-Nazi organisations, the SD has worked to distance itself from its history, repeatedly reprimanding and expelling members for being 
openly racist or using violent rhetoric (Ekman and Poohl 2010). The SD’s official rhetoric is no longer a vulgar, coarse racism but a nuanced, strategically designed ideology that nevertheless fails (or is not intended) to distance the party from fundamental ideas of race (mediated through concepts such as ethnic groups, natural residence, nationality, ethnicity and culture). For instance, a party-produced campaign video for the 2010 election features women dressed in niqab, many pushing baby strollers and one wearing a diamond ring, competing against an old, grey-haired, light-skinned, purely ‘Swedish’ woman (Sverigedemokraterna \& Axelsson 2010). This video follows the SD’s strategy of pitting groups against each other, particularly the needs of the elderly against the supposed costs of refugees. In this film, the niqab-dressed women run with determination, while the elderly 'Swedish’ woman painfully pushes a walker towards an administrative desk representing the Swedish state budget. The desk has two emergency brake handles_one labelled pensions, which is implied that the niqab-dressed women want to grab, and one labelled immigration, for which the older 'Swedish’ woman, as a representative of the ‘Swedish’ people, reaches (Mulinari and Neergaard 2015).

The SD’s success in the 2010 and 2014 national elections raises the question of who votes for the party. The available statistics, especially those from SCB's party-sympathy polls and exit polls, should be read as indications at best. These polls have performed exceptionally poorly at predicting the SD’s performance in election results, often underestimating actual votes. Based on Statistics Sweden’s party preference polls ${ }^{\mathrm{iii}}$ the support for SD by sex and foreign- or native-born status has since 2010 (when they entered the Parliament) developed as follows. In 2010, 4.6 percent Swedish-born men preferred SD peaking with 21.1 in 2015 declining to 18.5 percent in 2017. In 2010, 1.6 percent foreign-born men preferred SD peaking with 12.6 in 2017. Of Swedish born women 2.2 percent preferred SD in 2010 and rose to 9.2 percent in 2017, which is fairly similar to the trajectory foreign-born women 
preferring SD 1.4 percent in 2010 and 9 percent in 2017. Thus, we see a strong rise in SD party preference, and a decreasing gap between foreign- and Swedish-born as well as between men and women.

Interestingly, the difference in party preference between Swedish- and foreign-born men is much larger than the difference between the groups of their female counterparts, likely due to the low percentage of Swedish-born women voting for the SD. One should also take into consideration the highly heterogeneous categories of foreign-born voters. Based on the regimes and constructions of racialisation and the SD's articulation of racism, along with other political questions, the SD's interpellation has different impacts on different groups of foreign-born and those with foreign backgrounds - an issue examined more thoroughly in the following sections.

\section{Theoretical framework: Migrant respectability}

At a descriptive level, the term respectability refers to seeking to make oneself socially acceptable through "good” or “proper” behaviour. Scholars from different traditions have described how hegemonic notions of what is normal, natural and right shape and regulate what and especially who are considered to be respectable citizens.

British labour-history scholars use the concept of respectability to explore workingclass culture, or rather, labour aristocracy and its identification with Victorian notions of respectability (Hobsbawm 1968). Following this tradition gender scholars have explored women’s central roles in establishing hierarchies between (white) workers in England, through notions of respectability, regulated through the private, home environment (Davidoff and Hall 1992; Walkowitz 1980). Ellen Ross (1985) argues that, in pre-war London 
neighbourhoods, women embodied respectability or the lack of it in their dress, public speech, childrearing and especially in private home-making. An emphasis on their shared values with majoritized society through the prisma of respectability has been central in unprivileged groups struggles for social justice (Higginbotham 1993; White 2001, Harris 2014).

Victoria Wolcott’s (2001) analysis of African American women in interwar Detroit illustrates how fundametnal respectability frames are in political mobilisation. However, respectability politics may reinforce notions of a post-racial society, locating racism in the past (Goldberg 2015). Studies on ethnicity and migration in Europe so far have had little to say about respectability (Gallo and Scrinzi 2016). In an exploration of Irish identities, Mervin Busteed (2009) uses the concepts of cultural hegemony and subaltern resistance to grasp the experiences of Irish migrants in Victorian Britain, analysing how they conformed to dominant expectations for upwards social mobility.

This study is inspired by feminist scholar Beverley Skeggs’ (1997) efforts to think of respectability as at the cross-roads of social relations (formations of class and gender in her study, the Swedish racial regime in the present analysis) and lived experience. The concept of racial regime (Mulinari and Neergaard 2017b) provides a structural and materialistic understanding of the fundamental role that race as a classificatory system plays in the reproduction of inequalities and a conceptualisation of race understood as a fluid and unstable category of social meaning constangly being transformed by cultural, social and political conflict (Winant and Oni 1994: 59). Thus, migrant respectability as a sensitive concept opens for an exploration of racialized groups strategies towards experiences of exploitation, discrimination and marginaliation.

The present analysis takes inspiration from Skeggs' (1997) conceptualisation of respectability as a form of capital and from Davis and Harre understanding of migrant 
respectability as subject positions (1990). This opens up a fluid, dynamic understanding of how selves are constructed both by the power of classifications and cultural hegemony and by the many, often contradictory discourses that a particular subject position acts upon as forms of subordination and strategies of negotiations and resistance. In the next section we briefly outlines the methodological design and the material used in this article. Then, the analytical section operationalises the theoretical framework in light of the material.

\section{Methods and material}

To study a political party whose politics the researchers strongly dislike and to conduct this study in the condition of non-Swedes (one author has a Latin-American refugee background, the other is an Afro-Swede) were serious challenges. Central to the methodological strategy was an attempt to diminish the boundary between us (good antiracists) and them (bad racists) by implementing an intersectional approach.

The authors consider the SD be a racist party and thus a threat to themselves and their communities, but the informants, in many ways, had experienced more exploitation and subordination based on the intersection of class, gender and, in some cases, racialisation than the researchers' experiences as non-white, upper middle-class male and female scholars. Thus, an intersectional edge in the analysis provided a productive strategy for thinking the positionality and politics of locations (Yuval Davis 2011) and permitting understanding of the informants’ worldviews.

The empirical material evolved from an on-going qualitative study started in 2008. The research was inspired by the contributions of feminist methodologies' efforts to explore positionality (Haraway 1988) and answer the difficult questions contained in the question: 
what side are you on, and why (Armbruster and Lærke 2008)? This research consisted of interviews and textual analysis of SD documents, media and secondary literature. The interviews with women SD activists included as many of the (few) female SD municipal and regional representatives as possible, including all those of migrant backgrounds (determined by names or information found in the media). Of the approximately 20 interviews conducted, five of the informants were born outside Sweden (including one identified during the interview). The semi-structured interviews lasted 45 minutes to 2 hours, conducted in the Swedish and translated to English by the authors. The questions did not include references to sensitive terms, such as migrants, ethnicity, racism and similar issues, to avoid weakening the material by cooking the data. All the references to these issues made by the informants were given in answers to questions concerning why they joined SD, what they saw as major political issues and how they understand Sweden today.

This article grew forth based on a small group of migrants within a larger study of women activists within the SD. The limited interview material was complemented by searching for newspaper articles interviewing migrant SD activists and the few references to these questions in the secondary literature. As the issues of identities, worldviews and respectability became central in the analysis, we increasingly included material from earlier studies, and especially a study of the association of Trade Union Active Immigrants (Author 2004). This also include research on articles written by established cultural workers with migrant backgrounds. Thus, the material encompass migrant activists’ accounts and selfperception of their practices.

\section{Migrants, subject positions and respectability strategies}


The previous sections have introduced the theoretical framework focussing on the concepts of subject position and respectability. In the following, these concepts are operationalised through variations in positioning and strategies analysed in the research material. This exploration is located in the complex web of continuities and sometimes radical changes in the ways that migrants individually and collectively challenge the subject positions prescribed to them by the Swedish racial regime. Subject positions that vary over time, but may also be contradictory at the same time: a burden to the welfare state, a problem to be solved and the re-invention, in recent years, as a dangerous threat to Swedish values and norms (Mulinari and Neergaard 2017a).

The linkages of particular strategies of migrant respectability with different subject positions are theoretically understood through the concept of structural selectivity (Jessop 1990) (or possibilities), emphasising tendencies, not automatic outcomes. Studies, particularly in social psychology, have analysed the process of individual and collective dis-identification through the concept of defensive othering, or 'identity work done by those seeking membership in a dominant group, or by those seeking to deflect the stigma they experience as members of a subordinate group' (Schwalbe et al. 2000, 425). Departing from a dialogue between earlier research and an inductive readings of migrants' stories from interviews and self-written texts we bring about a number of forms of respectabilities. A typology that is partially overlapping and not necessarily complete, and thus more of an approach in being than a consistent theoretical perspective.

Coping migrant respectability is a positioning predominant among migrants performing and making immense efforts to produce good migrants in the context of structural and institutional racism and subordinated migrant organisations. Any member of migrant communities (as the authors are) or unprivileged groups can often recognise the socialisation patterns and forms of social control within their communities that enable the performance of 
coping (migrant) respectability. This often entails, for instance, being polite to members of the majority population, speaking the majority language in public, not showing anger, not acting out of place, being always grateful and working almost twice as hard.

A second subject position within the frame of migrant respectability is based on an understanding of ethnic discrimination and the struggle to integrate migrants into the frame of the established political parties and civil society. Here labelled anti-discrimination respectability, this position entails self-representation of migrants as sharing similar values as the majority population and being well-educated and well integrated but within a worldview that acknowledges suffering ethnic discrimination as central to the migrant experience.

A third subject position has evolved since Sweden's shift towards Fortress Europe, with the emergence of various discourses in mainstream public media and political parties presenting migrants as a threat to the nation's values and/or economy. Successful migrant respectability regulated through a notion of desirable migrants has developed, to a certain extent, in response to these transformations. Within a neoliberal frame, this subject position celebrates the individuality of migrants (Andersen 2005), especially those with Muslim backgrounds who distance themselves from other Muslims (Razack 2008) and those in positions of power who deny the existence of racism in Sweden.

The fourth subject position constructs respectability within a frame of self-defence as migrants pursue a strategy of des-identification from being the migrant Other, that see themselves as assimilated. Most of these migrants are from the era of labour migration and are at least partially deracialised (passing as white), but they also include political refugees who have dominated migration since the 1970s. In this article, this strategy is termed racist migrant respectability and, in the analysis, emerges as a major feature of migrant SD activists. 
While these variations in respectability are all understood as self-defence positions, a fifth transcends the limitations of performing for the majority population. This (oppositional migrant) position is especially linked to growing groups dominated by Swedish-born youth of migrant parents and often organised in separatist and autonomous networks. This subject position is based on refusing to subordinate oneself to what is understood as systemic or structural racism, emphasising the need to transgress and challenge any form of migrant respectability. Often inspired by slogans such 'as 'your silence will not protect you', those who adopt this subject position aim to challenge the hegemony of whiteness at the core of classification system regulating the right to belong and be considered 'Swedish'. We identify this oppositional identity is here labelled antiracism as non-respectability.

Needless to say, this research approaches these five subject positions as analytical models and sensitising concepts in an ideal-type form. Next, the concrete analysis explores migrants' understandings of themselves and others at the individual and the collective levels within the dynamic interactions with these subject positions.

\section{From coping migrant respectability to antiracist non-respectability}

In this section, four of these five subject positions are shortly discussed and illustrated: successful migrant respectability, anti-discrimination respectability, coping migrant respectability and antiracism as non-respectability. The fifth subject position racist migrant respectability will be discussed in the following section. Swedish postcolonial scholars (de los Reyes, Molina and Mulinari 2002) have identified the subject position of successful migrant respectability when analysing how gender equality, understood as a Swedish value, acts as a fundamental boundary defining those who belong and do not belong to the nation. Both women and men with migrant backgrounds who engage in public des-identification from their 
own culture (particularly Muslim backgrounds) are publicly recognised as desirable migrants and welcomed into their new nation home as migrant gate-keepers. This category of desirable migrants within the subject position of successful respectability frequently consists of migrants identified with the right-wing project defending the neoliberal agenda that seldom acknowledges and most often obscures racism. What lends this category of migrants a veneer of respectability is among other things, their public stories of individual success, labelling other migrants' focus on racism as an obsession. This approach is exemplified in State Secretary for the Minister for Integration Jasenko Selimovic’s response (2013) to an open letter on racism in Sweden addressed to Minister of Justice Beatrice Ask and written by Jonas Hassen Khemiri (2013), a well-known postcolonial fiction writer. Selimovic argues that migrants have exaggerated racism instead of focusing on working hard towards integration (2013). He further maintains that both he and the letter writer are illustrations of how marginal racism in the country is.

Anti-discrimination migrant respectability is well illustrated by an intervention by a popular Swedish hip-hop singer. In November 2013, hip-hop artist Jason Diakité ('Timbuktu') visited the Swedish Parliament to perform and receive an award from a humanrights antiracist organisation for his work against discrimination. The singer represents a wellestablished form of hip-hop which is both a product of and a response to the SD project and its crisis (Sernhede 2002) and offers a well-articulated criticism of the loss or decline of the Swedish welfare state. The song, Svarta Duvor och Vissna Lilljor finds its point of departure in a cultural artefact (Diakité's Swedish passport) to argue that attacks to his person cannot be considered to be xenophobic: he is not a stranger; he was born and raised in Sweden. The song lyrics focus on his wish to be evaluated by his merits, not his skin colour, and end with a demand to be seen and acknowledged as a Swedish citizen. In the text, Diakité works dynamically with concepts of nationhood, moving fluently from defining Sweden as a nation- 
state ('When I leave Sweden, I take my passport with me') to focusing on civil society ('I demand to be seen as a part of this society') and to imagining a community of belonging (paraphrasing the national anthem, 'I will love in Sweden, I will live in Sweden and I will die in Sweden’) (Sveriges Radio 2013). Diakité did not receive the award from Per Westerberg, the speaker of Parliament from the right-wing Moderaterna party. Westerberg, refused, arguing that one of Diakité's songs instigated violence. In particular, Westerberg objected to the lyrics 'beating Jimmie Åkesson yellow and blue', a phrase linking the chairman of the racist SD party with the colours of the Swedish flag (Tagesson 2013). While this subject position allows much criticism of racism and demands that migrants be recognised as members of the nation, it often also makes an implicit pledge of loyalty to the nation. In other words, the intervention writes itself into earlier forms of migrant respectability conceptualised here as anti-discriminatory migrant respectability.

Mustafa Can, a well-known Swedish journalist, wrote a piece on the experiences of his father, a migrant from Kurdistan with a working-class background. The article describes the painful strategies that his father (and migrant men in general) was forced to adopt in an attempt to be accepted in the nation.

My father stands up for everyone on the bus even when there are vacant seats so that no one will think that he, a migrant worker, is ignorant, impolite or uneducated. He holds doors open, sometimes for minutes, and nods in a friendly way to all who pass so that no one will think that he is ungrateful to the people who received him. He never crosses the street on a red light even if it's the middle of the night, and there are no cars in sight so that no one will think that he does not understand. ... He works double shifts at Volvo, keeps its workplace clean and cleans the toilet after everyone so that no will think that migrants are dirty. [He] goes to work even when he can barely stand on 
his feet, and he thanks and bows when the foreman says he's doing a good

job. And he thanks and bows again when the same person announces,

'Unfortunately, you cannot be promoted this year either' (Can 2014).

Can's father embodies the coping migrant respectability as a way to protect himself, his family and the migrant community, so 'they [the Swedes] cannot say that we [the Kurds or the migrants] are not clean, behave badly or do not work hard' (Can 2014).

Can argues that, although his father did everything right, his actions were never enough. He concludes the article by vowing that, if someone challenges his belonging to the nation, he 'never, never, never will show his passport; instead, he will show his finger'. Can embodies a new generation of Swedish citizens with migrant backgrounds who have found 'that working hard, being nice and smiling all the time' (Can 2014) do not help. This generation has developed a more confrontational language expressed in literature, art and politics (Mulinari and Neergaard 2017b). 'To show the finger' embodies a search for a new political rethoric that confronts notions of tolerance (Brown 2006) central to both coping and antidiscriminatory migrant respectability. 'To show the finger' decentres the white (Swedish) gaze and seeks other ways of understanding self-and others outside the realm and the harm of racism. Today, this emergent oppositional position is linked with a strategy defined here as antiracism as non-respectability.

Exploring the diverse forms of migrant respectability emerging as a response to the Swedish racial regime creates an approach that avoids pathologising the migrants who choose to support or be active in the SD. Instead, this framework locates the racist migrant respectability of our informants in the Swedish context where migrants' inclusion in the nation as equal citizens is always and systematically contested. 
Answering this article's starting question of why migrants become active in a racist party, here, the SD, Pontus Mattsson (2009) identifies two categories of migrants: labour migrants and groups who have experienced the position of religious minorities in states dominated by repressive Islamic governments (Poohl 2010). Historian Lena Lodenius adds, in an interview, a third category: migrants who identify with the SD’s strong conservative values, which are exceptional in Swedish policy (Ljungberg \& Hashemi 2013). ${ }^{\text {iv }}$ Anna Hagwall, a Hungarian immigrant who, until her recent expulsion for antisemitism (Jeppsson \& Karlsson 2017), was one of the relatively few women in high positions in the SD, highlights a different argument. She explains SD support from people with Eastern Europe backgrounds as grounded in their successful integration and rise to the middle class (Poohl 2010).

Similarly, Nima Gholam Ali Pour, who was chairman of a Socialdemocratic party (SDP) neighbourhood association in Malmö some years ago, left the SDP when a member of the party of Muslim background, who was a board member of the Islamic Association, was elected to the SDP's national board. Pour, defends the SD , arguing that the first thing that even a migrant who comes to Sweden with the aim of contributing to the country understands is that the current Swedish migration policy is unsustainable. He cites the municipal support given to refugees by integration officers during the family-reunion process as an example of the refugee policy's unsustainability. According to Pour, this is proof of a society that does not even demand that migrants speak Swedish to bring their families to the country. Pour continues to argue that he does not understand why he, as a migrant, would not support a party that seeks to control migration (Ljungberg \& Hashemi 2013).

His argument that migrants perceive (perhaps better than the Swedes) the unfairness in the system between those who work and those who cheat (e.g. migrant criminals, welfare dependants) is a point repeated in all our interviews. ${ }^{\mathrm{v}}$ 
Why should we, Swedes, that is to say, real Swedes_- I am a foreigner-pay

and put them in prison? It costs a lot of money every day. (Informant 5) ${ }^{\mathrm{vi}}$

The most salient point in this quotation is the shift from the 'we' at the beginning of the sentence to the 'I' who acknowledges that the informant is not a 'real Swede'. The ways in which migrant SD activists talk about migrants, refugees and especially Muslims are often shaped by their own understandings of themselves, their struggles and what differentiates them from migrant Others.

The stories of the migrant SD representatives emphasise their successful integration compared to what they see as a cultural failure or unwillingness among new migrants to integrate or assimilate. According to the informants, this successful integration is achieved primarily by learning Swedish, marrying a Swede (some stated that their Swedish partners brought them into the SD) and distancing themselves from other migrants who do not want to integrate. However, most of the informants with foreign backgrounds have difficulty narrating successful labour-market or family stories as, with one exception, they all had long experiences of precarity, early retirement, unemployment and sick leave (Mulinari and Neergaard 2014).

While it is difficult to generalise from the limited empirical material, it seems that these migrants are marginal not only in the labour market, like many Swedish women in the SD (Mulinari and Neergaard 2015), but also in migrant organisations and diaspora networks (although some did see themselves through the lens of their country of birth).

Our informants tell migration stories consisting of hard work, willingness to integrate or assimilate and success in doing so: 
I came here, learned Swedish and worked hard, and here I am. It doesn’t need to be more complicated than this. ... I'm unemployed now but have been working for many years. (Informant 2)

I came here thinking, 'I'm in Sweden, then it's the Swedish language that applies’. No complaining and crying. No nonsense. (Informant 3)

In the first quotation, a silence occurs between the first and the second part of the informant's narrative. Perhaps as the interviewer remains silent and does not acknowledge the informant's 'success', she feels obliged to explain that her situation of unemployment is different from those of the refugees she so actively opposes. The second informant (Informant 3) uses the phrase 'no nonsense' to formulate a description of a pragmatic, instrumental self that has successfully learned Swedish and sees others struggling against ethnic discrimination as crying and complaining.

The informants' narratives are framed in juxtaposition to their own careers in Sweden as assimilating, law-abiding migrants who accept the rules. The narratives are sometimes explicitly framed in opposition to the form of anti-discrimination respectability that has succeeded in putting the issue of ethnic discrimination on the public agenda:

We took the jobs that Swedes didn’t want and worked from day one. We moved around looking for jobs. We paid taxes and did not go around screaming racism everywhere. (Informant 4)

A similar but slightly different intervention is expressed as follows:

I think it's great that they [the SD] dare to stand up for it [Critique of the Swedish generous migration and refugee policy] and that they dare to speak out loud about what the Swedish people only talk about at the kitchen table 
and out in the cottages. And I know that, when I meet Swedes who do not know me, they are so very careful. But then, when I bring up the subject myself, then they will begin to talk. Otherwise, they dare not for they would immediately get the stamp of being racist. And what they say-elderly, ordinary people, Swedish workers who have retired - they say that nobody asked them if they wanted foreigners in their buildings. So, I must say, they [other migrants in the neighbourhood] destroy a lot. They have somehow started now-I do not know how — to get our houses; they can afford to buy the condominiums. And then it happens that they are forced to sell for they cannot pay for it. I sit on the [condominium] board here, too, so I have some insight on that: it's a disaster. We always had such fine order in the laundry room and in the garden and the basement. They are moving in more and more; they are destroying the area. I asked them before. I went to them and asked them, 'Why move here if you cannot follow the rules?' 'Because it is so nice here', they answered. 'But why do you think it is so nice here?' 'Because we keep everything clean and in order'. That's it; that's what people see. Now, I'm not saying that all of them are like this or do this, but the ones I have met are like this. (Informant 3)

In this narrative, the informant's migrant background hinders candid conversations with Swedes who do not know her well. The argument that 'everybody thinks like us, but nobody has the courage to speak' is very common among SD members, here expressed in the fantasy of what people actually say around their kitchen tables. The rhetoric of 'out in the cottages' follows the SD's nostalgic view of Sweden as rural. The narrative about the Swedish elderly is also important in the general SD interpellation as elderly adults support the party to a greater extent than other age groups. Finally, a consistently defensive racism ('I am not saying 
that all of them are like this or do this, but ...') reflects rhetoric common in many interviews with Swedish members of the party. In telling these stories of racist migrant respectability, hard work and integration or assimilation they present today's migrants as negations. As one of the informants describes today's immigrants, 'they cheat', 'they are lazy', and 'they do not want to work’ — the reverse of how the migrants in our sample depict themselves.

These migrants share a similar position with the female, Swedish-born SD members interviewed characterised by a weak labour-market position and welfare dependence (Mulinari and Neergaard 2014). Studies on gender and nationalism point to the central role women play in these movements (Yuval Davis 1997) and the forms of empowerment that participation in them provide women (Blee 1996). This, we would like to suggest, does not hold true for migrants The strategy of racist migrant respectability tends to leave these migrants isolated between the SD that might accept them but only in a subordinate position and the migrant communities that actively distance themselves from them. Razack (2004) suggests in her study of Islamophobia in Canada that coming out as anti-Islam is a successful career strategy. While the same process occurs in Sweden, those coming out in this way must be young, middle class and articulated when speaking to the media and 'beautiful' as objects of white/western desire,. In contrast, racist migrant respectability does not provide immediately successful career paths for migrants in our sample.

\section{Racist migrant respectability and boundary-making: European, white and Christian}

Opposition to Islam seems to be a very important condition making migrants eligible for recruitment to the party. For instance, an Arabic website posted a video in which the SD chairman promised to support Christian Arab immigration in return for support of the party’s agenda of decreasing Muslim immigration (Hallberg and Jonblat 2010). The SD’s successful recruitment of eight individuals of Iraqi backgrounds in Södertälje, a major city near the 
capital Stockholm, for the 2010 municipal election was presented as a demonstration that the party was not racist. This group supported the SD based on attraction primarily to racism against Muslims but also to the SD’s reactionary ideology concerning gender and sexuality. However, the group (including half of the SD’s municipal council representation in Södertälje) left the party in 2012, arguing that they, although Christian, were treated as inferior (Pettersson 2012). To the extent that migrants cannot pass as

Swedish/western/European, their support for the SD seems to be quite volatile and liable to end abruptly. Despite the number of possible complex reasons, it seems that being classified as from the Global South is a significant factor in defining non-belonging to the nation.

The informants interviewed suffered forms of racialisation in Sweden regarding their national and ethnic backgrounds, names and ways of speaking. They, however, often also draw boundaries between themselves and the other migrants based on the informants' shared ‘European values’.

It is different. Of course, there are cultural differences between me and the Swedes, ... but ... we-how can I put it?—come from the same civilisation ... immigrants and immigrants. I am from here, the same religion, the same civilisation, the same European values. They are different, those who are coming now. (Informant 1)

The informants often identify themselves as sharing a common (Christian) European tradition (what they call 'civilisation'). They emphasise the new migrants' distance from Sweden as Muslim and Arab and generally stress that the new migrants are substantially different and want to live differently in 'enclave societies' or, even worse, take over and dramatically transform Sweden in their own image, in what the informants term the 
Islamisation of Sweden. While the boundary-making discussed in the previous subsection emphasises laziness and conveys a generalised aversion only partially linked to migrants being Muslim and Arabic, the second centres on being Muslim, which the interviewees define as the antithesis of being Swedish (and of assimilating). The informants' understanding confirms that whiteness (coded as Christian) is at the core of the construction of Swedishness and especially in boundary-making regarding national belonging.

\section{Conclusions}

We have in these pages analysed racialized groups strategies targeting the field of the political through location forms of migrant respectability with the Swedish racial regime. We have argued that gaining respect in migrants' new "national home” is a goal for which various groups suffering racialisation strive. While most migrants do so by opposing, in diverse ways, the SD, the Swedish extreme-right wing and racist party, a few do so through choosing to support this racist party.

Extreme right-wing or what the researchers consider to be racist parties have become increasingly institutionalised in many parliaments of Western Europe. This indicates that these parties' electorate and representatives come from many groups in their respective societies, although most have overrepresentations of white, working-class or petitebourgeoisie men. However, some women from majority populations and both male and female migrants who suffer racialisation vote for and represent these parties. Focussing on these migrant activists, this research analyses two ways that boundary-makings are used to support forms of racist migrant respectability. Divisions are drawn between, on one hand, cheaters and hard-working migrants and, on the other, white European Christians and Muslims. 
The group which in many ways seem to be a possible stable base of support for the SD consists mostly of migrants from Europe, including Eastern European political refugees, labour migrants, family reunification/love migrants and (white) migrants from other Nordic countries. In the analysis of their narratives, they see themselves as the silent workers who have built the Swedish welfare society. Although earlier research showed that these groups were racialised and discriminated against, their narratives seldom include experiences of discrimination, though they often link their support for the SD to their suffering and plight as workers doing the jobs Swedes disdain. Racist migrant respectability is a crucial aspect of their self-identification, and they deploy it against other groups of today's migrants who are unemployed and rely more heavily on welfare benefits. Expressing a need to defend their status, the informants see new migrants/refugees and, to a certain extent, these migrants' children as threats. Being a desirable migrant is an unstable position actively reproduced in relation to the non-desirable migrant, a category that, amid increasing right-wing, xenophobic racism, is central to boundary-making in public debates.

The study results point to three directions for further research. One is to develop a new research field—of which this article seems to be an early work — on migrants' support for and activism within racist parties not only in Sweden but also more broadly in the Nordic and European contexts. The second research direction concerns how migrants and racialised groups deal with the issues of respectability, recognition and allegiance to the country in which they live and how they realise similar ideas in completely different ways. At the core of these issues lies migrants' varying ways of participating in the (re)construction of the Swedish nation. Finally, a third but important research agenda which has been toned down in the article is the need to explore gender and respectability—both for dominant and racialisedconcerning racism and the extreme right (Köttig, Bitzan and Petö 2017). 
Funding

This work was supported by the Vetenskapsrådet (Swedish Research Council) [Grant Dnr 2007-7269], Vetenskapsrådet (Swedish Research Council) [Grant Dnr 2016-05186].

\section{References}

Ålund, Aleksandra, and Carl-Ulrik Schierup. 1991. Paradoxes of Multiculturalism: Essays on Swedish Society. Aldershot: Avebury.

Andersen, Margaret L. 2005. ‘Thinking about Women: A Quarter Century’s View’. Gender \& Society 19 (4): 437-55.

Anthias, Floya. 2002. 'Where Do I Belong? Narrating Collective Identity and Translocational Positionality’. Ethnicities 2 (4): 491-515.

Armbruster, Heidi, and Anna Lærke. 2008. Taking Sides: Ethics, Politics and Fieldwork in Anthropology. New York: Berghahn Books:

Blee, Kathleen 1996. 'Becoming a Racist: Women in Contemporary Ku Klux Klan and NeoNazi Groups’. Gender \& Society 10 (6): 680-702.

Brown, Wendy. 2006. Regulating Aversion: Tolerance in the Age of Identity and Empire. Princeton: Princeton University Press.

Busteed, Mervyn. 2009. 'Resistance and Respectability: Dilemmas of Irish Migrant Politics in Victorian Britain’. Immigrants \& Minorities 27 (2-3): 178-193.

Can, Mustafa. 2014. “Jag Tänker På de Andra, Svarar Far.” HD. (http://www.hd.se/2014-0103/jag-tanker-pa-de-andra-svarar-far accessed April 24, 2017). 
Castles, Stephen, and Godula Kosack. 1973. Immigrant Workers and Class Structure in Western Europe. London: Oxford University Press.

Castles, Stephen, and Mark J. Miller. 2003. The Age of Migration. Basingstoke: Palgrave.

Dahlstedt, Magnus, and Fredrik Hertzberg. 2005. 'Demokrati på Svenska? Om strukturell diskriminering och politiskt deltagande’ (Democracy in Swedish? On Structural discrimination and political participation). SOU 2005:112.

Davidoff, Leonore, and Catherine Hall. 1992. Family Fortunes: Men and Women of the English Middle Class, 1780-1850. London: Routledge.

Davies, Bronwyn, and Rom Harré. 1990. 'Positioning: The Discursive Production of Selves’. Journal for the Theory of Social Behaviour 20(1): 43-63.

de los Reyes, Paulina, Irene Molina and Diana Mulinari (2002). Maktens (o)lika förklädnader. Kön, Klass och etnicitet i det postkoloniala Sverige [Same and different disguises of power. Gender, Class and Ethnicity in post-colonial Sweden]. Stockholm: Atlas.

Ekman, Mikael and Daniel Poohl. 2010. Ut ur skuggan: en kritisk granskning av Sverigedemokraterna (Out of the shadows. A critical analysis of the Sweden Democrats). Stockholm: Natur \& Kultur.

Esping-Andersen, Gøsta. 1990. The Three Worlds of Welfare Capitalism. Cambridge: Polity.

Gallo, Ester, and Francesca Scrinzi. 2016. Migration, Masculinities and Reproductive Labour: Men of the Home. Basingstoke: Palgrave Macmillan.

Gardell, Mattias. 2010. Islamofobi. Stockholm: Leopard.

Goldberg, David T. 2015. Are We All Postracial Yet? Cambridge: Polity Press.

Göransson, Anita. 2005. Makten och mångfalden: eliter och etnicitet i Sverige (Power and diversity: Elites and ethnicity in Sweden). Stockholm: Fritzes. 
Hallberg, Jenny, and Firas Jonblat. 2010. “Kristna Irakier Hoppas På Asyl Av SD.” Sveriges Radio. (http://sverigesradio.se/sida/artikel.aspx?programid=3993\&artikel=4072597 accessed April 24, 2017).

Haraway, Donna. 1988. 'Situated Knowledge. The Science Question in Feminism and the Privilege of Partial Knowledge’. Feminist Studies 14: 249-263.

Harris, Fredrick C. 2014. 'The Rise of Respectability Politics’. Dissent 61 (1): 33-37.

Higginbotham, Evelyn Brooks. 1993. Righteous Discontent: The Women's Movement in the Black Baptist Church, 1880-1920. Cambridge: Harvard University Press.

Hobsbawm, Eric J. 1968. Labouring Men: Studies in the History of Labour. London: Weidenfeld and Nicholson.

Jeppsson, Jonathan, and Pär Karlsson. 2017. “Anna Hagwall Utesluten Ur SD - Blir Vilde.” Aftonbladet. (http://www.aftonbladet.se/nyheter/samhalle/article24047522.ab accessed April 24, 2017).

Jessop, Bob. 1990. State Theory. Putting Capitalist States in Their Place. Cambridge: Polity Press.

Keskinen, Suvi. 2014. 'Re-constructing the Peaceful Nation: Negotiating Meanings of Whiteness, Immigration and Islam after a Shopping Mall Shooting’. Social Identities 20 (6): 471-485.

Khemiri, Jonas Hassen. 2013. “Bästa Beatrice Ask.” DN.SE. (http://www.dn.se/kulturnoje/basta-beatrice-ask/ accessed April 24, 2017).

Köttig, Michaela, Andrea Bitzan, and Andrea Petö. 2017. Gender and Far Right Politics in Europe. Palgrave Macmillan. 
Ljungberg, Anders, and Zinat Hashemi. 2013. “Allt Fler Män Med Utländsk Bakgrund Stöder SD - Radio Sweden På Svenska.” Sveriges Radio.

(http://sverigesradio.se/sida/artikel.aspx?programid=3993\&artikel=5730771 accessed April 24, 2017).

Mattsson, Pontus. 2009. Sverigedemokraterna inpå bara skinnet (The Swedish Democrats, next to the skin). Stockholm: Natur \& Kultur.

Melby, Kari, Christina Wetterberg, and Anna.-Birte Ravn. 2008. Gender Equality and Welfare Politics in Scandinavia: The Limits of Political Ambition? Bristol: Policy Press.

Mudde, Cas. 2010. The Populist Radical Right: A Pathological Normalcy. West European Politics 33 (6): 1167-1186.

Mulinari, Diana, and Anders Neergaard. 2004. Den nya svenska arbetarklassen: rasifierade arbetares kamp inom facket [The new Swedish working class: the struggle of racialised workers within the trade union]. Umeå: Boréa.

Mulinari, Diana, and Anders Neergaard. 2012. 'The Sweden Democrats, racisms and the construction of the Muslim threat.’ In Morgan, George and Scott Poynting (Eds.), Global Islamophobia: Muslims and Moral Panic in the West (p. 67-82). London: Ashgate.

Mulinari, Diana, and Anders Neergaard. 2014. 'We are Sweden Democrats because we care for others: Exploring racisms in the Swedish extreme right.' European Journal of Women's Studies, 21(1), 43-56.

Mulinari, Diana, and Anders Neergaard. 2015. 'Racist dreams and municipal budgets: women representing a culturally racist party in local politics. Social Identities, 21(5), 506-523.

Mulinari, Diana, and Anders Neergaard. 2017a. 'From racial to racist state? The Sweden Democrats reimagining the nation.’ In Ålund, Aleksandra, Carl-Ulrik Schierup and Anders 
Neergaard (Eds.), Reimagineering the Nation. Essays on Twenty First Century Sweden (p. 257-284). Frankfurt am Main: Peter Lang.

Mulinari, Diana, and Anders Neergaard. 2017b. Theorising racism: exploring the Swedish racial regime. Nordic Journal of Migration Research, 7(2 (June)).

Neergaard, Anders \& Woolfson, Charles 2017, in print. Sweden: A model in dissolution? In Marino, Stefania, Judith Roosblad and Rinus Penninx (Eds.), Trade Unions, Immigration and Immigrants in Europe in the 21th Century: New Approaches under Changed Conditions. Cheltenham: Edward Elgar-ILO.

Pervó, Davide, and John Solomos. 2013. Migrant Politics and Mobilisation: Exclusion, Engagements, Incorporation. London: Routledge.

Pettersson, Roland. 2012. “De Lämnar SD För S.” Lt.se. (http://www.lt.se/stockholm/sodertalje/de-lamnar-sd-for-s accessed April 24, 2017).

Poohl, Daniel. 2010. “Malmös Nya Ansikte.” Tidningen Expo. (http://expo.se/2010/malmosnya-ansikte_3189.html accessed April 24, 2017).

Razack, Sherene. 2004. 'Imperilled Muslim Women, Dangerous Muslim Men and Civilised Europeans: Legal and Social Responses to Forced Marriages’. Feminist Legal Studies 12(2): 129-174.

Razack, Sherene. 2008. Casting out: The Eviction of Muslims from Western Law and Politics. Toronto: University of Toronto Press.

Ross, Ellen. 1985. “"Not the Sort that Would Sit on the Doorstep”: Respectability in PreWorld War I London Neighborhoods'. International Labor and Working-Class History 27: 39-59. 
Schierup, Carl-Ulrik and Aleksandra Ålund. 2011. 'The End of Swedish Exceptionalism? Citizenship, Neoliberalism and the Politics of Exclusion’. Race \& Class 53 (1): 45-64.

Schwalbe, Michael, Sandra Godwin, Daphne Holden, Douglas Schrock, Shealy Thompson, and Michele Wolkomir. 2000. 'Generic Processes in the Reproduction of Inequality: An Interactionist Analysis’. Social Forces 79 (2): 419-452.

Selimovic, Jasenko. 2013. ”Jonas, Min Vän”. DN.SE. (http://www.dn.se/kulturnoje/kulturdebatt/jonas-min-van/ accessed April 24, 2017).

Sernhede, Ove. 2002. Alienation is my Nation: Hiphop och unga mäns utanförskap i Det nya Sverige (Alienation is my Nation: Hiphop and young men exclusion in the New Sweden). Stockholm: Ordfront.

Skeggs, Beverley 1997. Formations of Class and Gender. Becoming Respectable. London: Sage.

Skey, Michael. 2011. National Belonging and Everyday Life. Basingstoke: Palgrave Macmillan.

Sverigedemokraterna and Michael Axelsson. 2010. Sverigedemokraternas officiella reklamfilm, tv4 [Sweden Democrats’ Official Commercial, tv4] ( http://www.youtube.com/watch?v=5UiUdpYVubY accessed April 24, 2017).

Sveriges Radio. 2013. “Rapper’s Lyrics Prompt Snub from Politicians - Radio Sweden.” http://sverigesradio.se/sida/artikel.aspx?programid=2054\&artikel=5723943 accessed April 24, 2017).

Tagesson, Eric. 2013. “Talmannen Bojkottar Timbuktu-Pris.” Aftonbladet. (http://www.aftonbladet.se/nyheter/article17961166.ab accessed April 24, 2017). 
Walkowitz, Judith R. 1982. Prostitution and Victorian Society: Women, Class, and the State. Cambridge: Cambridge University Press.

White, E. Frances. 2001. Dark Continent of Our Bodies: Black Feminism and the Politics of Respectability. Philadelphia. Temple University Press.

Wolcott, Victoria W. 2001. Remaking Respectability: African American Women in Interwar Detroit. Chapel Hill. N.C. University of North Carolina Press.

Yuval Davis, Nira. 1997. Gender and Nation. London: Sage Publications.

Yuval Davis, Nira. 2011. The Politics of Belonging. Intersectional Contestations. London: Sage Publications.

\footnotetext{
i In this article, the term 'migrants' is used to refer to this heterogeneous group of SD activists who, in different ways, have been and are racialised. The authors are well aware that both the processes and the experiences of racialisation vary for those who can and those who cannot pass as 'Swedish'.

${ }^{\text {ii }}$ Moderata samlingspartiet, M. 1997. Land för hoppfulla: manifest för ett nytt sekel. Moderata samlingspartiet. iii See

http://www.statistikdatabasen.scb.se/pxweb/sv/ssd/START_ME_ME0201__ME0201B/Partisympati19/?rxid= 8fcaa278-e6dd-4704-b89b-bb471d842bcd (retrieved Nov 09, 2017).

${ }^{\text {iv }}$ Although the Christian Democrats have competed on conservative gender and sexuality values, they have gradually adapted these positions in response to their alliances with liberal parties and generally have been staunch defenders of a comparatively generous refugee policy.

v Also see the SD’s 2014 election video featuring two racialised representatives and party leader Jimmie Åkesson.

vi To protect the participants’ anonymity, they are identified by numbers, not names.
} 